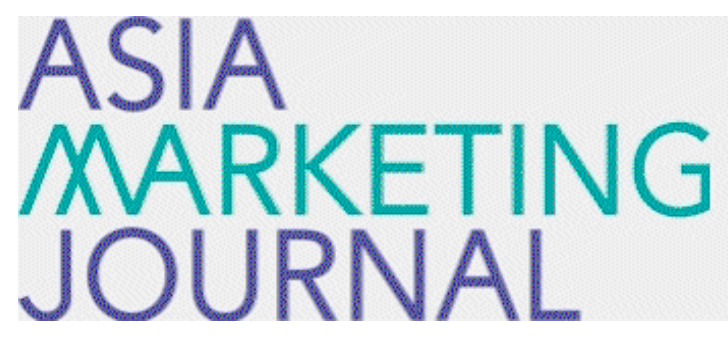

ASIA MARKETING JOURNAL

Volume 22 | Issue 4

Article 10

$1-31-2021$

\title{
The Editorial for the Special Session Papers of ICAMA-KAS 2020 International Conference: BTS as a Paradigm Changer in Martech and/or Innovation
}

\author{
Sungho Lee \\ Kyunghee Bu \\ Jaehwan Kim \\ Ji Hee Song
}

Follow this and additional works at: https://amj.kma.re.kr/journal

Part of the Marketing Commons

\section{Recommended Citation}

Lee, Sungho; Bu, Kyunghee; Kim, Jaehwan; and Song, Ji Hee (2021) "The Editorial for the Special Session Papers of ICAMA-KAS 2020 International Conference: BTS as a Paradigm Changer in Martech and/or Innovation," Asia Marketing Journal: Vol. 22 : Iss. 4 , Article 10.

Available at: https://doi.org/10.53728/2765-6500.1374

This Article is brought to you for free and open access by Asia Marketing Journal. It has been accepted for inclusion in Asia Marketing Journal by an authorized editor of Asia Marketing Journal. 


\section{The Editorial for the Special Session Papers of ICAMA-KAS 2020 International Conference: BTS as a Paradigm Changer in Martech and/or Innovation}

Sungho Lee*

Kyunghee $\mathrm{Bu}^{* *}$

Jaehwan Kim***

Ji Hee Song****

This editorial briefly explains the overview of the special session papers of ICAMA (International Conference of Asian Marketing Associations)-KAS (Korea Advertising Society). We also present the general direction for progressing the development of AMJ. Most of all, this special session was made possible because of the contribution of Professor Kyunghee Bu, the Rhizomatic Revolution Review and the BTS ARMY.

Keywords: ICAMA-KAS, BTS, the ARMY, the development of AMJ

We are delighted to publish this issue with the papers that have passed examination among the papers presented at the ICAMA-KAS 2020 conference. It seems to be even more meaningful as AMJ has rarely published special session papers through international conferences. In 2020, the Korean Marketing Association held ICAMA and ICAMA-KAS conferences, thanks to Chairman Sang man Han's leadership. In particular, AMJ had a great deal of concern as it competed with the recruitment of special session papers from leading international and SSCI-indexed journals such as Journal of Business Research, International Journal of Advertising, Asia Pacific Journal of Marketing and Logistics, and International Journal of Research in Marketing. In the meantime, thanks to Professor Kyunghee Bu's ability,

\footnotetext{
* Editor-in-Chief, Professor, University of Seoul (shlee@uos.ac.kr)

** Guest Editor, Professor, Kwangwoon University (khbu@kw.ac.kr)

*** Guest Editor, Professor, Korea University (jbayes@korea.ac.kr)

**** Guest Editor, Professor, University of Seoul (jiheesong@uos.ac.kr)
} 
which Chairman Han invited, the Korean Marketing Association and AMJ have a new and innovative experience. It was nothing but a meeting with BTS' fan club, ARMY. Prof. $\mathrm{Bu}$, who is also a member of ARMY, introduced the launch of the R3 (the Rhizomatic Revolution Review Journal; https://ther3journal.com/). This fusion journal pursues various interdisciplinary research centering on BTS. She presented the idea of AMJ and R3 collaboration and the theme of special session, i.e., BTS: A Paradigm Changer in Martech or Innovation. As a result, 21 participants presented their papers in a non-face-to-face manner on October 31, 2020. Finally, seven articles were then published on this issue. In particular, on the day of the conference, compared to other sessions, the number of participants reached 200-300. Hence, the Korean Marketing Association and AMJ confirmed the intense interest in BTS even in the academic community. The brief overview of the papers are presented in the following.

First, Bu and Kim's article suggests that with shared SNS episodes we can examine celebrity-endorsed ad effects. It empirically shows far more positive SNS responses to episode-type advertising than a traditional image-oriented ad. We think that suggesting the form of effective advertising communication in the contexts of fandoms and SNS is a managerially useful implication.

Episodic advertising has common aspects with the themes of the other two articles. Lazore examined the importance of storytelling in building the BTS brand. As per managerial implication, Lazore proposed the specific components of successful storytelling as follows: 1) story as central to the brand, 2) authenticity and sincerity, 3) idol participation in creative output, 4) use of transmedia storytelling and story gaps, 5) intertextuality and cohesion, 6) opportunities for audience engagement and 7) dedicated creative staff. From a little different angle, Piccialli showed the importance of meaning-making through the case study research, which analyzed the cross-artistic project Connect, BTS and its relationship to transmedia branding, meaningmaking, and spatiality.

The other two articles share the fan's theme in terms of supportive, voluntary, non-monetary behaviors. Proctor showed the role fans played as supporting representatives with rapid speed, termed as organized labor network due to affect. Similarly, Donabedian examined fan-led financial and support initiatives such as the affective properties of music consumption, the parasocial relationship, fan community dynamics, and the purchase of intimacy. The author interpreted these initiatives as the exchange of intimacy between fans and artists. These two studies also share the commonality in terms of the method: participant observation and interviews.

Lastly, two papers recorded BTS-related events in detail and interpreted their meaning. 
de Jesus introduced live streaming called "BangBangCon: The Live" in particular. It was interesting to see the functional interpretation of digital contents of videos, photos, and music from product innovation. Blady looks at BTS's main albums' songs in detail but shows content analysis and interpretation from a unique perspective. It is none other than consistent mental health messaging and modeling of various mental health modalities. Primarily, creating a peer support community within the group extended to their fanbase ARMY. Fancreated mental health programs have emerged with the topic of mental health well-being and recovery. This evolution is an innovative and exciting case. It seems to be very meaningful if it leads to future research that interprets it with a more theoretical frame.

Next, we will summarize the development direction of AMJ internationalization. First of all, the publication of 204 English papers in 34 issues since the publication of English papers in October 2012 is a truly phenomenal result.

However, AMJ's biggest weakness is that citations of articles have been lowered due to insufficient efforts to improve papers' accessibility and readability. It is not appropriate to publish English papers and maintain the registered journal accreditated by the Korea Research Foundation. Specifically, in domestic academic journals, citations from Korean papers and papers from internationally renowned academic journals are natural, whereas citations from
English papers published in Korea are unnatural. As a result, AMJ's Korea Citation Impact index is falling despite the increasing number of English papers. The AMJ and the editorial board are in a frustrating situation.

In the end, to increase the readership and citation of the documents, an open-access journal publication contract with an international publisher is the first condition for success. Funding is required to achieve this condition, and for this, the presidents of the Korean Marketing Association will make more special efforts.

The second condition is that AMJ can be reborn as a real international academic journal only when the contributors' nationality diversity is improved. From this point of view, we must continue collaboration with the R3 journal and the Army. Of course, we also need this kind of additional collaboration effort to continue such internationalization. In this respect, the issue of this special session is more meaningful. We hope you sincerely observe and support AMJ's development in the future. We hope you enjoy reading the interesting papers on this issue.

〈Received February 14. 2021〉

〈Accepted February 18. 2021〉

\section{References}

Https://ther3journal.com/ 